\title{
The incidental capture of seabirds by Spanish drifting longline fisheries in the western Mediterranean Sea*
}

\author{
JULIO VALEIRAS ${ }^{1}$ and JUAN ANTONIO CAMIÑAS ${ }^{2}$ \\ ${ }^{1}$ Instituto Español de Oceanografía, Centro Oceanográfico de Gijón, Avda Principe de Asturias, 70 bis, 33212 Gijón, \\ Asturias, Spain. E-mail: xulio.valeiras@gi.ieo.es \\ ${ }^{2}$ Instituto Español de Oceanografía, Centro Oceanográfico de Málaga, Puerto Pesquero s/n, 29640 Fuengirola, \\ Málaga, Spain.
}

\begin{abstract}
SUMMARY: The western Mediterranean Sea is an important fishing area for the Spanish drifting longline fleet, targeting swordfish (Xiphias gladius), bluefin tuna (Thunnus thynnus) and albacore (T. alalunga). Some seabird species can be captured incidentally as bycatch marine fauna. From July 1999 to August 2000 information on 554 surface longline sets was collected by onboard observers of the Spanish Oceanographic Institute (IEO) on 18 longline fishing boats working within the Spanish Mediterranean fishing area. Eleven yellow-legged gulls (Larus cachinnans), 9 Cory's shearwaters (Calonectris diomedea) and 1 Northern gannet (Morus bassanus) were captured incidentally. Bycatch rates ranged from 0.002 to 0.023 birds/1000 hooks.
\end{abstract}

Key words: incidental capture, bycatch, seabirds, drifting longline, Mediterranean.

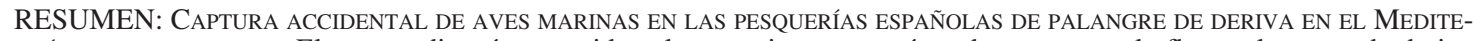
RRÁNEO OCCIDENTAL. - El mar mediterráneo occidental es una importante área de pesca para la flota palangrera de deriva española, centrando su actividad sobre el pez espada (Xiphias gladius), el atún (Thunnus thynnus) y la albacora (T. alalunga). Algunas especies de aves marinas pueden ser capturadas accidentalmente por estas artes de pesca. Desde julio de 1999 hasta agosto de 2000 se recogió información en 554 palangres de superficie por observadores de abordo del Instituto Oceanográfico Español (IEO) en 18 barcos palangreros trabajando en la zona de pesca mediterránea española. Resultaron capturadas accidentalmente 11 gaviotas patiamarillas (Larus cachinnans), 9 pardelas cenicientas (Calonectris diomedea) y un alcatraz (Morus bassanus). Las tasas de capturas oscilaron entre 0,002 a 0,023 aves/1000 anzuelos.

Palabras clave: captura accidental, aves marinas, palangre de deriva, Mediterráneo.

\section{INTRODUCTION}

Bycatch by drifting longlines is considered an important threat for the conservation of several seabird species (Brothers et al., 1999). Bycatch by longliners in Antarctic waters is probably the most important threat to albatross populations (Tasker et al., 2000). Scientific data on bycatch in the western Mediterranean Sea are scarce (Cooper et al., in this volume). The western Mediterranean Sea is an

\footnotetext{
*Received October 11, 2001. Accepted October 9, 2002.
}

important fishing area where the Spanish drifting longline fleet target swordfish (Xiphias gladius), bluefin tuna (Thunnus thynnus) and albacore ( $T$. alalunga). Incidental captures by drifting longliners include several species of seabirds.

The International Action Plan of the FAO (IPOA/Seabirds) regarding incidental capture of seabirds by longline fisheries started in 1999. FAO members agreed to develop National Action Plans to assess incidental catch by country (Anonymous, 1999). The Spanish Oceanographic Institute (IEO) developed a monitoring programme of incidental 
captures by drifting longline fisheries working in the western Mediterranean since 1976. Surveys onboard commercial drifting longliners were carried out from 1999 to 2000 within the project EMTP, a European project on bycatch funded by IEO and EU (DG Fisheries). In this paper, we present the first data on seabird bycatch by Spanish drifting longlines in the western Mediterranean in order to assess the potential importance for seabird conservation.

\section{MATERIAL AND METHODS}

The study area includes the fishing area of the Spanish drifting longline fleet in the western Mediterranean. Data on fisheries bycatch were collected from July 1999 to August 2000. Scientific observers worked onboard 18 longliners targeting swordfish, bluefin tuna and albacore from five different base ports (Cartagena, Águilas, Garrucha, Carboneras and Motril). Data collection and survey strategies were divided into two strata by type of fleet and four strata by type of drifting longline gear. A monthly research programme was undertaken along the whole fishing area. Data on 557 fishing sets were collected following standardised fishing parameters:

- Detailed description of types of gear used: swordfish, bluefin tuna and albacore drifting longlines and swordfish semipelagic longline.

- Fishing strategies, scheme and fleet dynamics.

- Technical characteristics of fishing sets, including geographic position, duration, depth, baits, type of setting, etc.

- Environmental factors and meteorological conditions, including measures of surface temperatures, and fishing depth and temperature by specific sensors attached to gears.

- Detailed data on commercial and incidental catches of marine species.

Total annual fishing effort by longline type (swordfish, bluefin tuna and albacore) were not available during the analysis as a consequence of the number of landing ports, fishing periods and heterogeneous fleets.

The Spanish drifting longline fleet consists of 72 licence vessels from 4 to $22 \mathrm{~m}$ in length. The fishing grounds include a large area of the western Mediterranean between $36^{\circ}$ and $44^{\circ} \mathrm{N}$ and $-02^{\circ} \mathrm{W}$ and $05^{\circ} \mathrm{E}$ (Camiñas and De la Serna, 1995; Camiñas and Valeiras, 2001). The most important fishing effort is carried out around the Balearic Islands and in the Ibiza Channel. The fleet is very dynamic and often changes fishing methods as well as gear structures. The type of gear used depends on season, target species, fishing yields and fishing area (Valeiras and Camiñas, 2001).

The fleet use 4 types of drifting longlines with some differences in structure and target species: longline for swordfish, longline for bluefin tuna, longline for albacore tuna and semipelagic longline for swordfish. Fishing gears are made up for a main line, from 19 to $60 \mathrm{~km}$ in length, equipped with 1,500-4,000 branch lines. Floats keep the main line near the surface. Hooks are baited with fish (e.g. mackerel, sardine, scabbard fish) and shortfin squid (Illex spp.). Semipelagic longlines are set with weights which maintain the gear deeper. Longlines for swordfish are set late in the afternoon and remain overnight. Hauling starts in the first hours of the morning and finishes usually by dawn. Longlines targeting bluefin tuna and albacore can be set during both night and day hours.

\section{RESULTS}

A large number of seabirds approach boats during fishing operations. The following species were observed during the onboard surveys attending fishing operations, but no bycatches were recorded: the lesser black-backed gull (Larus fuscus), Audouin's gull (L. audouinii), the Balearic shearwater (Puffinus mauretanicus), terns (Sterna sp.) and the Euro-

TABLE 1. - Observed fishing sets and observed fishing effort (thousands of hooks) by year.

\begin{tabular}{|c|c|c|c|c|c|c|}
\hline Drifting longline gear & $\begin{array}{c}1999 \\
\text { Observed sets }\end{array}$ & Hooks (x1000) & $\begin{array}{c}2000 \\
\text { Observed sets }\end{array}$ & Hooks (x1000) & $\begin{array}{c}\text { Total } \\
\text { Observed sets }\end{array}$ & Hooks (x1000) \\
\hline Swordfish & 202 & 587.7 & 148 & 461.7 & 350 & 1049.4 \\
\hline Semipelagic & 15 & 25.1 & 2 & 4.1 & 17 & 29.2 \\
\hline Bluefin tuna & - & - & 120 & 195.8 & 120 & 195.8 \\
\hline Albacore & 63 & 280.3 & 7 & 18.7 & 70 & 299.0 \\
\hline Total & 280 & 893.1 & 277 & 680.2 & 557 & 1573.4 \\
\hline
\end{tabular}


TABLE 2. - Total incidental catch and bycatch rates by species (number of birds / 1000 hooks).

\begin{tabular}{|c|c|c|c|c|}
\hline & 1999 & 2000 & Total & $\begin{array}{l}\text { Birds/ } \\
1000 \text { hooks }\end{array}$ \\
\hline \multicolumn{5}{|l|}{$\begin{array}{l}\text { Drifting longline gear } \\
\text { Larus cachinnans }\end{array}$} \\
\hline Swordfish & 1 & 7 & 8 & 0.0076 \\
\hline Semipelagic & 0 & 0 & 0 & \\
\hline Bluefin tuna & 0 & 0 & 0 & 0 \\
\hline Albacore & 3 & 0 & 3 & 0.0100 \\
\hline Total & 4 & 7 & 11 & 0.0070 \\
\hline \multicolumn{5}{|l|}{ Calonectris diomedea } \\
\hline Swordfish & 1 & 1 & 2 & 0.0019 \\
\hline Semipelagic & 0 & 0 & 0 & 0 \\
\hline Bluefin tuna & 0 & 0 & 0 & 0 \\
\hline Albacore & 4 & 3 & 7 & 0.0234 \\
\hline Total & 5 & 4 & 9 & 0.0057 \\
\hline \multicolumn{5}{|l|}{ Morus bassanus } \\
\hline $\begin{array}{l}\text { Swordfish } \\
\text { Sw }\end{array}$ & 0 & 0 & 0 & 0 \\
\hline Semipelagic & 0 & 0 & 0 & 0 \\
\hline Bluefin tuna & 0 & 0 & 0 & 0 \\
\hline Albacore & 1 & 0 & 1 & 0.0033 \\
\hline Total & 1 & 0 & 1 & 0.0006 \\
\hline \multicolumn{5}{|l|}{ Seabird bycatch } \\
\hline Larus cachinnans & 4 & 7 & 11 & 0.0070 \\
\hline Calonectris diomedea & 5 & 4 & 9 & 0.0057 \\
\hline Morus bassanus & 1 & 0 & 1 & 0.0006 \\
\hline Total & 10 & 11 & 21 & 0.0133 \\
\hline
\end{tabular}

pean storm petrel (Hydrobates pelagicus). Most of the birds attending drifting longliners were recorded during hauling when baits are dehooked and rejected by the crew.

Monitored fishing sets and fishing effort by type of gear and year (i.e. thousands of hooks) are shown in Table 1. Bycatch of seabirds in 557 fishing sets observed (15.7 million hooks) included three species: 11 yellow-legged gulls (Larus cachinnans), 9 Cory's shearwaters (Calonectris diomedea) and 1 northern gannet (Morus bassanus).

Results and bycatch rates by type of drifting longline gear observed (i.e. number of birds/1000 hooks) are given in Table 2. Drifting longlines targeting swordfish had a maximum bycatch rate of 0.0076 birds/1000 hooks. Albacore longline showed a bycatch rate of 0.0234 birds/1000 hooks. Bluefin tuna and semipelagic swordfish gears did not record any incidental catch.

\section{DISCUSSION}

Differences in bycatch rates can be explain by differential selectivity of the fishing gears. The gear targeting albacore has smaller hooks and bait (sardine) than the others. Swordfish longlines sink faster and operate deeper than the albacore gear, causing a reduced availability of baited hooks for scavenging seabirds. Furthermore, the fishing strategy targeting albacore includes more day time during setting and hauling operations. Bluefin tuna and semipelagic swordfish gears operate deep due to heavy components and fishing strategy.

Spatial distribution of bycatches was influenced by distance to the coast. Yellow-legged gull bycatches occurred close to the shore, whereas Cory's shearwater bycatches were distributed in pelagic waters often far from the coast (Table 3). These results agree with the different habits known for these two species, but the small number of seabird bycatches do not allow further conclusions on the spatial pattern of bycatch.

Temporal distribution of bycatch shows larger bycatch rates of gulls during the winter months. Fishing effort during March, in southern waters offshore the Balearic Islands, resulted in most of the yellow-legged gull bycatches (i.e. six birds during a single week). Meteorological conditions, rough seas and fishing operations near the shore during March 2000 explain this event, but migratory patterns must also be taken into account as an important factor affecting seabird abundance in time.

Most of the seabirds $(n=19)$ drowned after taking the bait and becoming hooked during setting operations. Two yellow-legged gulls were hooked during line hauling and released alive with slight injuries to their bills.

Preliminary data indicate that seabird incidental catch rates by Spanish drifting longline fisheries in the western Mediterranean targeting tuna species and swordfish are lower than in other fisheries studied. Bycatch rates (birds / 1,000 hooks) in tuna longline fisheries reach 0.360 in Southern African waters

TABLE 3. - Date and geographical position of the bycatches. The study area was subdivided into squares of $1 \mathrm{X} 1$ degree (LatitudeLongitude).

\begin{tabular}{|c|c|c|c|c|}
\hline Species & Fishing gear & Date & Area & $\mathrm{n}$ \\
\hline Calonectris diomedea & Albacore & 21/09/99 & $40 \mathrm{~N} 02 \mathrm{E}$ & 4 \\
\hline Calonectris diomedea & Swordfish & $30 / 10 / 99$ & $38 \mathrm{~N} 00 \mathrm{E}$ & 1 \\
\hline Calonectris diomedea & Swordfish & $26 / 03 / 00$ & $39 \mathrm{~N} 04 \mathrm{E}$ & 1 \\
\hline Calonectris diomedea & Albacore & $22 / 06 / 00$ & $38 \mathrm{~N} 04 \mathrm{E}$ & 3 \\
\hline Larus cachinnans & Albacore & $11 / 09 / 99$ & $41 \mathrm{~N} 03 \mathrm{E}$ & 3 \\
\hline Larus cachinnans & Swordfish & $08 / 12 / 99$ & $38 \mathrm{~N} 02 \mathrm{E}$ & 1 \\
\hline Larus cachinnans & Swordfish & $26 / 03 / 00$ & $39 \mathrm{~N} 04 \mathrm{E}$ & 2 \\
\hline Larus cachinnans & Swordfish & $28 / 03 / 00$ & $39 \mathrm{~N} 03 \mathrm{E}$ & 2 \\
\hline Larus cachinnans & Swordfish & $29 / 03 / 00$ & $39 \mathrm{~N} 03 \mathrm{E}$ & 1 \\
\hline Larus cachinnans & Swordfish & $06 / 04 / 00$ & $39 \mathrm{~N} 03 \mathrm{E}$ & 1 \\
\hline Larus cachinnans & Swordfish & $27 / 06 / 00$ & $37 \mathrm{~N} 01 \mathrm{~W}$ & 1 \\
\hline Morus bassanus & Albacore & $28 / 10 / 99$ & $41 \mathrm{~N} 03 \mathrm{E}$ & 1 \\
\hline
\end{tabular}


and 0.379 in Australasian waters (Ryan and BoixHinzen, 1998). Japanese tuna longline fisheries around Australia have caught 0.15 birds / thousand hooks (Gales et al., 1998). Bottom longlining in the Northeast Atlantic reaches bycatch rates of 1.05 birds / 1,000 hooks (Tasker et al., 2000). Comparisons between studies are for guidance only and standardisation of the catch data is necessary to assess differences. Assessment of drifting longline annual total bycatch needs more information on fleet dynamics, fishing periods and target species.

Population impact of bycatches on seabirds is poorly known at the moment. No mitigation measures to reduce seabird mortality were used in the study fishery. Data from Belda and Sánchez (2001) on seabird mortality on longlines around the Columbretes Islands (Spain) suggests that bycatch rates could be very variable at the local level, due to seabird distribution and also to the dynamics of the drifting longline fishing fleet. Owing to the existence of several large breeding colonies of seabirds in the western Mediterranean, seabird bycatch could be a cause for concern. Although our data are preliminary, we suggest the need to improve the monitoring of incidental bycatch of seabirds in the western Mediterranean.

\section{ACKNOWLEDGEMENTS}

This work was carried out within the framework of the project E.U. DG XIV - 98/008. We are grateful to all the onboard observers, 'cofradías' and fishermen. We also thank our colleagues of 'the Big
Pelagics scientific team of the IEO-Málaga, and two anonymous referees for their useful suggestions on the manuscript.

\section{REFERENCES}

Anonymous. - 1999. Report of the FAO Technical Working Group Meeting on Reduction of Incidental Catch of Seabirds in Longline Fisheries. FAO Fish Rep. No. 585.

Belda, E.J. and A. Sánchez. - 2001. Seabird mortality on longline fisheries in the western Mediterranean: factors affecting bycatch and proposed mitigating measures. Biol. Conserv., 98: 357-363.

Brothers, N.P., J. Cooperand and S. Lokkeborg. - 1999. The incidental catch of seabirds by longline fisheries: wordlwide review and technical guidelines for mitigation. FAO Fish Circ. No. 937. $100 \mathrm{pp}$.

Camiñas. J.A. and de la Serna J.M. - 1995. The loggerhead distribution in the western Mediterranean sea as deduced from captures by the Spanish long line fishery. In: Llorente, G.A., Montori, A., Santos, X. and Carretero, M.A. (Eds.). Sci. Herpet., 1995: 316-323.

Camiñas J.A. and J. Valeiras. - 2001. Proyecto europeo para la evaluación de las capturas accidentales de tortugas marinas en las pesquerías de palangre de superficie y arrastre en el Mediterráneo (EMPT). Primeros resultados. Primer Simposium de la SEC, Ceuta, 23-27 febrero 2000. Libro de resúmenes: 5-9

Cooper, J., N. Baccetti, E.J. Belda, J.J. Borg, D. Oro, C. Papaconstantinou and A. Sánchez. - 2003. Seabird mortality from longline fishing in the Mediterranean Sea and Macaronesian waters: A review and a way forward. Sci. Mar., 67(Suppl. 2):

Gales, R., N. Brothers and T. Reid. - 1998. Seabird mortality in the Japanese tuna longline fishery around Australia, 1988-1995. Biol. Conserv., 86: 37-56.

Ryan, P.G. and C. Boix-Hinzen. - 1998. Tuna longline fisheries off southern Africa: the need to limit seabird bycatch. S. Afr. J. mar. Sci., 94: 179-182.

Tasker, M.L., C.J.K. Camphuysen, J. Cooper, S. Garthe, W.A. Montevecchi and S.J.M. Blaber. - 2000. The impacts of fishing on marine birds. ICES J. mar. Sci., 57: 531-547.

Valeiras J. and J. A. Camiñas. - 2001. Captura accidental de tortugas marinas en las pesquerías españolas de palangre de pez espada y túnidos en el Mediterráneo. Libro de Resúmenes del $2^{\circ}$ Simposium de la Sociedad Española de Cetáceos, Valsaín (Segovia), Nov. 2001. 12-15. 